\title{
ANALISIS PERFORMANSI ROUTING PROTOCOL OLSR DAN AOMDV PADA VEHICULAR AD HOC NETWORK (VANET)
}

\author{
Rianda Anisia, Rendy Munadi, Ridha Muldina Negara* \\ Jurusan Teknik Telekomunikasi, Fakultas Teknik Elektro, Universitas Telkom \\ "Corresponding author, e-mail : ridhanegara@ telkomuniversity.ac.id
}

\begin{abstract}
Abstrak-Vehicular Ad-Hoc Network (VANET) merupakan pengembangan dari Mobile Ad-Hoc Network (MANET) yang menjadikan kendaraan sebagai node nya. Teknologi VANET diharapkan dapat meningkatkan keamanan pengemudi saat berkendara di jalan raya antara lain dengan adanya map location, informasi lalu lintas, peringatan jika akan terjadi tabrakan, dan akses internet pada kendaraan. Namun, VANET memiliki karakteristik jaringan yang cepat berubah karena pergerakan node yang cepat sehingga perlu dipilih protokol routing yang dinilai cocok dan efisien sehingga pengiriman data dapat berlangsug secara maksimal. Pada penelitian ini akan disimulasikan serta dianalisis perbandingan kinerja Optimized Link State Routing Protocol (OLSR) dan Ad Hoc On demand Multipath Distance Vector (AOMDV) menggunakan kondisi urban (perkotaan). Di lingkungan tersebut akan diuji perubahan kecepatan node dan pengaruh jumlah node. Simulasi ini dilakukan dengan menggunakan NS-2.34 dilengkapi dengan SUMO 0.12.3. sebagai mobility generator dan MOVE sebagai script generator Performansi diukur menggunakan parameter perbandingan berupa Average throughput, Packet Delivery Ratio, Average End-to-end delay, Normalized Routing Load, dan Routing Overhead. Hasil analisis di lingkungan VANET, protokol routing AOMDV lebih unggul dibandingkan protokol routing OLSR. Karena hampir pada semua parameter yang diujikan pada skenario perubahan jumlah node maupun kecepatan node AOMDV memiliki performansi yang lebih baik sehingga AOMDV lebih efisien digunakan pada kondisi lingkungan perkotaan.
\end{abstract}

Kata Kunci : VANET, NS-2, OLSR, AOMDV, SUMO,MOVE

\begin{abstract}
Vehicular Ad-Hoc Network (VANET) is a development of the Mobile Ad-Hoc Network (MANET), which makes the vehicle as its nodes. VANET technology is expected to improve the security of drivers while driving on a highway between the others, with the map location, traffic information, warning if there will be a collision, and internet access in the vehicle. However, VANET has the characteristics of a network rapidly changing due to the rapid movement of nodes that need to have a routing protocol that is considered suitable and efficient so that data transmission can be optimally lasts. This research will be simulated and analyzed the comparative performance of Optimized Link State Routing Protocol (OLSR) and Ad Hoc On-demand Multipath Distance Vector (AOMDV) using urban conditions (urban). The environment will be tested in speed changes and the effect of the number of nodes nodes. This simulation was done using NS-equipped with SUMO 0.12.3 2:34. as mobility MOVE as a script generator and generator Performance was measured using parameters such as Average throughput comparison, Packet Delivery Ratio, Average End-to-end delay, Normalized Routing Load, and Routing Overhead. Results of analysis in environmental VANET, routing protocols AOMDV superior routing protocol than OLSR. Because almost all parameters tested in scenarios of changes in the number of nodes and node speed AOMDV have better performance so AOMDV more efficient use on urban environmental conditions.
\end{abstract}

Keywords : VANET, NS-2, OLSR, AOMDV, SUMO, MOVE

Copyright $\odot 2016$ JNTE. All rights reserved

\section{PENDAhuluaN}

Teknologi wireless yang baru-baru ini menjadi topik penelitian yang semakin berkembang adalah Vehicular Ad hoc Network (VANET). Tujuan dasar VANET adalah untuk mengembangkan sistem komunikasi kendaraan sehingga memungkinkan pertukaran data yang cepat dan efisien untuk kepentingan keamanan dan kenyamanan pengendara serta dapat digunakan sebagai sistem informasi trafik lalu lintas yang cerdas. VANET merupakan suatu jaringan ad-hoc yang bersifat self-organizing yang bekerja pada sistem intervehicle communication (IVC) dan vehicle - to infrastructure communication yang juga 
merupakan subkelas dari mobile ad-hoc network (MANET)[1]. Pada penelitian sebelumnya[2] menunjukkan bahwa meskipun protokol routing MANET dapat diterapkan pada VANET tapi ketika kepadatan dan kecepatan kendaraan meningkat kinerja protokol akan semakin menurun.

Permasalahan utama yang biasa terjadi pada lalu lintas di kota-kota besar adalah kemacetan dan kecelakaan. Hal tersebut biasanya disebabkan oleh kepadatan jumlah kendaraan dan kecepatan kendaraan. VANET yang menggunakan kendaraan sebagai node nya tentu akan memerlukan implementasi routing protocol yang sesuai dengan karakteristik jaringan nya. Protokol routing berdasarkan topologi merupakan salah satu kategori protokol routing pada VANET. Lalu protokol routing tersebut di bagi tiga yaitu proactive, reaktive dan hybrid. Pada routing proaktif, protokol menentukan table routing nya dengan mengupdate setiap waktu jika terjadi perubahan link. Salah satu contoh routing ini adalah OLSR, setiap node pada OLSR mengirimkan pesan control secara berkala dan tidak memerlukan pengiriman pesan berurutan. Sedangkan routing reaktif melakukan pencarian rute ketika suatu node akan mulai melakukan komunikasi dengan node lain. Salah satu routing protocol reaktif MANET yang sudah teruji di VANET adalah $A d$ hoc On-Demand Distance Vector (AODV). Dari routing protocol AODV itu kemudian dikembangkan routing protocol AOMDV. Perbedaan utama antara AODV dan AOMDV terletak pada jumlah rute yang ditemukan dalam tiap pencarian rute atau route discovery.

Oleh karena itu pada penelitian ini dilakukan analisis performansi protocol routing OLSR dan AOMDV pada jaringan VANET yang disimulasikan dengan Network Simulator 2.34 (NS-2.34). Dari kedua protokol routing diatas akan dibandingkan mana yang paling efisien dan performansinya paling maksimal pada kondisi urban di area perempatan lampu merah di sekitar jalan Ir. H. Juanda dan jalan layang Pasupati di daerah Dago Kota Bandung. Daerah tersebut dipilih karena memiliki karakteristik jalan persimpangan yang lebih dari satu. Kemudian skenario nya berupa perubahan jumlah node dan perubahan kecepatan node untuk inter vehicle communication (IVC). Performansi dapat ditinjau dari lima parameter berikut, yaitu Average throughput, Packet Delivery Ratio,
Average End-to-end delay, Normalized Routing Load, dan Routing Overhead.

\section{TINJAUAN PUSTAKA}

\subsection{Routing Protocols}

Pada penelitian ini kami menggunakan protokol routing berbasis topologi. Protokol routing berdasarkan topologi menggunakan link informasi yang ada dalam jaringan untuk melakukan forwarding paket ${ }^{[3]}$. Routing berbasis topologi ini dibagi lagi menurut sifatnya yaitu, proaktif, reaktif, dan hybrid. Pada penelitian ini kami menggunakan protokol routing proaktif OLSR dibandingkan dengan protokol routing reaktif AOMDV.

\subsubsection{Proactive Routing Protocol, OLSR}

Optimized Link State Routing Protocol (OLSR) adalah protokol routing proaktif yang dalam menentukan tabel routing nya dengan mengupdate setiap waktu jika terjadi perubahan link. Menggunakan teknik yang disebut Multipoint Relaying untuk meminimalkan overhead jaringan karena proses flooding untuk pengaturan rute. Pada OLSR ada 3 level optimasi yang dicapai ${ }^{[4]}$ yaitu :

1. Beberapa node yang terpilih sebagai Multipoint Relays (MPRs) untuk membroadcast pesan selama proses pengiriman paket.

2. Pencapaian optimasi dengan menggunakan MPRs untuk mengumpulkan informasi link state. Hasil pencapaian ini adalah meminimalisasi jumlah dari pesan kontrol proses yang ada dalam jaringan.

3. MPRs dapat memilih report dari link yang berada di antara node itu sendiri dengan node yang terpilih sebagai node MPR dari node tersebut. Hasil pencapaian ini adalah distribusi dari informasi partial link state dalam network tersebut.

Sebelum antar node dapat berkomunikasi suatu routing protokol melakukan suatu fase yang bernama route discovery yang berfungsi sebagai pembutan jaringan. System dari rute discovery dari OLSR adalah dengan mengirimkan pesan RREQ keseluruh node yang menjadi neighbour node tersebut untuk membuat suatu hubungan kesetiap node yang ada di jaringan tersebut, dan setiap node memiliki perhitungan tersendiri untuk mencapai 
suatu node dengan menggunakan algoritma shortest-path.

Setiap node menentukan node tetangganya yang mentransmit pesan pesan dari node tersebut, node tersebut disebut dengan MPRs, dalam menetukan MPRs setiap dua hop tetangga dari MPRs tersebut memiliki simpul dua arah menuju MPR set, sehingga MPR node harus berhubungan dengan dua tetangga node. Sebuah node mentransmisikan pesan hanya jika itu bagian dari MPRs set node yang yang telah dikirmkan pesan, jadi setiap node memlihara daftar node yang terpilih sebagai MPR ${ }^{[5]}$. Proses ini terlihat pada Gambar 1 dan Gambar 2 dibawah ini.

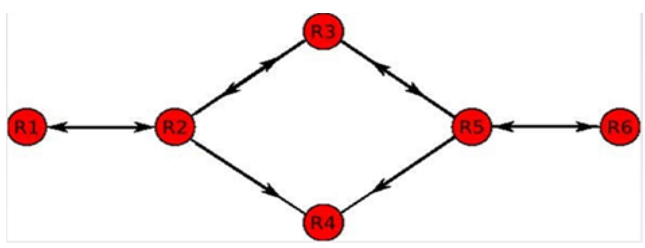

Gambar 1. MPR set ${ }^{[6]}$

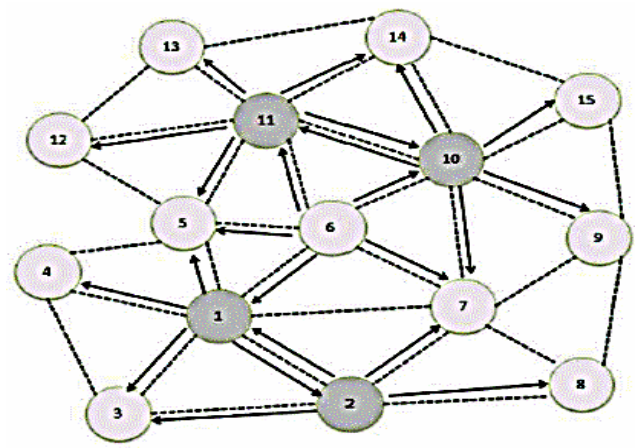

Gambar 2. OLSR Routing Network ${ }^{[7]}$

\subsubsection{Reaktive Protocol, AOMDV}

Ad Hoc On-Demand Multipath Distance

Vector (AOMDV $)^{[8]}$ adalah routing protocol reaktif pengembangan dari protokol routing unipath AODV untuk meminimalisir seringnya terjadi kegagalan hubungan dan rute yang terputus. Sama hal nya dengan routing protocol lainnya, AOMDV juga menyediakan dua layanan utama yaitu route discovery dan maintenance. AOMDV memiliki beberapa karakteristik yang sama dengan AODV. AOMDV berbasis vektor dan menggunakan pendekatan hop-by-hop. Bahkan, AOMDV juga hanya melakukan pencarian rute ketika dibutuhkan dengan menggunakan prosedur route discovery. Perbedaan utama antara AODV dan AOMDV terletak pada jumlah rute yang ditemukan dalam tiap kali pencarian rute atau route discovery. AOMDV dalam pencarian rute tidak seperti AODV yang hanya memilih satu RREP, tetapi pada AOMDV setiap RREP akan dipertimbangkan oleh node asal sehingga beberapa path bisa ditemukan dalam satu pencarian rute. Dengan ditemukannya beberapa path atau pilihan rute, apabila terjadi kegagalan rute maka dapat dialihkan ke rute alternatif lain. Dan pencarian rute baru hanya akan dilakukan apabila semua rute yang sudah ditemukan mengalami kegagalan. AOMDV memiliki tiga kelebihan dibanding multipath routing lain yaitu. Pertama, AOMDV tidak memiliki overhead koordinasi antar node yang tinggi karena komunikasi pada AOMDV hanya dilakukan saat dibutuhkan saja. Kedua, AOMDV menjamin rute alternatif saling disjoint atau beririsan melalui komputasi yang terdistribusi pada tiap node tanpa perlu komputasi dari node sumber saja sehingga rute yang ditemukan diharapkan tidak akan terjadi loop. Ketiga, AOMDV menghitung atau menemukan alternatif rute dengan tambahan overhead yang minim dibandingkan dengan AODV. Hal tersebut dilakukan dengan memanfaatkan semaksimal mungkin informasi routing jalur alternatif yang sudah ada. Inti dari protokol AOMDV adalah menjamin multiple path yang ditemukan adalah loop-free, disjoint, dan efisien dalam pencariannya. Aturan update rute pada AOMDV dilakukan secara mandiri oleh tiap node.

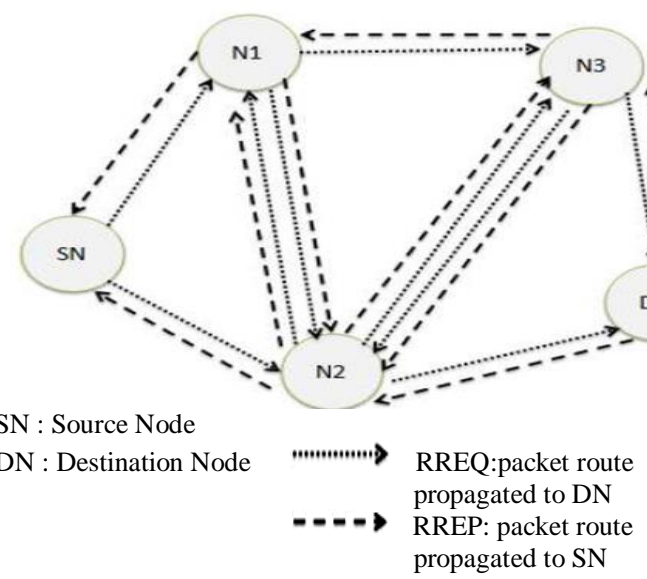

Gambar 3. Propagation of RREQ (Route Request) \& RREP (Route Reply) packet in $\mathrm{AOMDV}^{[7]}$ 
Pada Gambar 3 memperlihatkan langkahlangkah protokol AOMDV dalam melakukan pencarian rute (route discovery) dan pemeliharaan rute (route maintenance), yaitu:

1. Ketika source node akan melakukan komunikasi dengan node tujuan, maka S akan melakukan flooding paket route request (RREQ) ke jaringan.

2. Karena RREQ membanjiri jaringan, sebuah node mungkin dapat menerima beberapa salinan dari RREQ yang sama. Jika pada AODV, hanya salinan yang pertama yang digunakan untuk membuat reverse paths lain halnya dengan AOMDV.

3. Pada AOMDV, semua salinan RREQ diperiksa untuk membuat reverse paths alternatif, tapi reverse paths hanya dibuat menggunakan salinan RREQ yang dapat mempertahankan loop-freedom dan disjointness mulai dari node asal.

4. Ketika intermediate node menerima reverse path melalui salinan RREQ, node ini akan mengecek apakah ada satu atau lebih forward paths ke destination yang valid. Jika ada, node ini akan membuat paket RREP dan mengirim kembali melalui reverse path ke source node.

5. Saat destination node menerima salinan RREQ, node tsb juga membuat reverse paths dengan cara yang sama dengan yang dilakukan oleh intermediate node. Namun, RREP yang dibuat oleh destination dibuat dengan aturan yang lebih "longgar". Maksudnya adalah destination bisa mengirim RREP melalui reverse path yang loop-free tanpa harus disjoint. Hal ini dilakukan untuk mencegah "route cutoff" atau rute yang dihapus karena terjadi suppressing atau ketika sebuah node harus memilih satu dari dua atau lebih path.

6. Route maintenance pada AOMDV adalah penambahan sederhana pada AODV. Sama seperti AODV, AOMDV menggunakan paket RERR (Route Error). Sebuah node akan membuat atau meneruskan paket RERR untuk destination saat path terakhir ke destinasi rusak. AOMDV juga melakukan optimisasi untuk menyelamatkan paket yang sedang dikomunikasikan lewat link yang rusak dengan meneruskan ulang paket tersebut melalui jalur alternatif.

\section{METODOLOGI ATAU TEORI}

\subsection{Perancangan Sistem}

Pada simulasi ini menggunakan inter vehicle communication dengan membandingkan routing protokol berbasis topologi yaitu OLSR dan AOMDV dilakukan dengan beberapa ketentuan sebagai berikut:

1. Dalam simulasi VANET diasumsikan tiap node untuk menggambarkan tiap kendaraan.

2. Mendesain lingkungan simulasi yang sesuai dengan kondisi lalu lintas kendaraan di dunia nyata, sehingga dipilih lingkungan jalan diperkotaan (urban).

3. Menggunakan Random Way Point untuk mendesain pergerakan node sehingga dapat mensimulasikan kendaran yang sebenarnya.

4. Saat konfigurasi mobilitas node perlu di perhatikan skenario perubahan jumlah node dan kecepatan node karena berpengaruh pada performansi jaringan VANET.

5. Posisi dari tiap node di-generate secara teratur pada tujuan dan arah tertentu, menyesuaikan kondisi jalan yang dilalui kendaraan.

6. Kecepatan tiap-tiap nodenya disesuaikan dengan skenario lingkungan pada simulasi yang dijalankan di atasnya. Simulasi ini menggunakan domain wireless 802.11p dengan parameter jaringan ad hoc.

7. Patching dan konfigurasi protokol routing OLSR dan AOMDV pada Simulator NS-2.34 agar dapat digunakan pada simulasi ini.

8. Background Traffic arus data yang digunakan adalah Constant Bit Rate (CBR) dan node saling berkomunikasi melalui User Datagram Protocol (UDP).

9. Menghasilkan parameter keluaran yang dibutuhkan yaitu Packet Delivery Ratio, Average Throughput, Average End to End Delay, Normalized Routing Load, dan Routing Overhead.

\subsection{Alur Simulasi}

Dalam pengerjaan penelitian ini, setelah mengumpulkan referensi materi dan studi literature terkait, lalu mulai merancang simulasi skenario. Setelah itu mengambil peta di openstreetmap.org seperti contoh di Gambar 4, kemudian di edit oleh aplikasi JOSM untuk mengatur peta jalan sesuai dengan rencana skenario seperti jumlah jalur, penempatan posisi lampu lalu lintas, dan sebagainya. Kemudian di 
convert dalam format .net.xml. Selanjutnya membuat script arah pergerakan node dengan mengatur flow nya di .rou.xml. Adapun maksud dari flow disini adalah jalur yang ditentukan saat pembuatan pergerakan keadaan di dalam SUMO. Contoh hasil terlihat seperti di Gambar 5.

Node yang dipilih sebagai pengirim dan penerima hanya sample untuk menunjukkan performansi dari routing protocol tersebut. Kemudian keduanya digabungkan menjadi sumo.cfg agar dapat dijalankan menggunakan SUMO. Jika simulasi berhasil dilanjutkan dengan mengubah format script ke ".tcl" menggunakan MOVE. Script tersebut di running di NS-2.34 dan menghasilkan keluaran file.tr dan .nam. Langkah terakhir yaitu menjalankan file.awk menggunakan file.tr tadi sehingga menghasilkan parameter keluaran berupa Packet Delivery Ratio, Average Throughput, Average End to End Delay, Normalized Routing Load, dan Routing Overhead. Simulasi yang dilakukan berdasarkan parameter pada Tabel 1 Selanjutnya akan dianalisa performansi kedua protokol routing yang telah diuji.

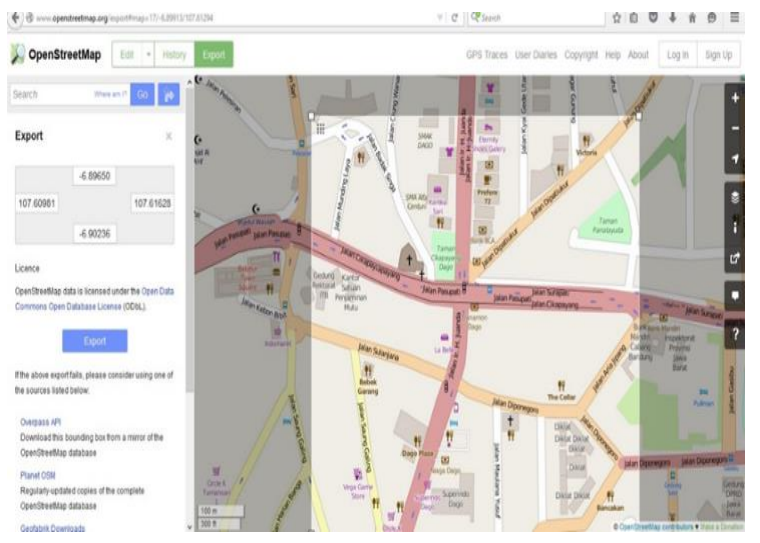

Gambar 4. Pengambilan peta jalan di openstreetmap.org

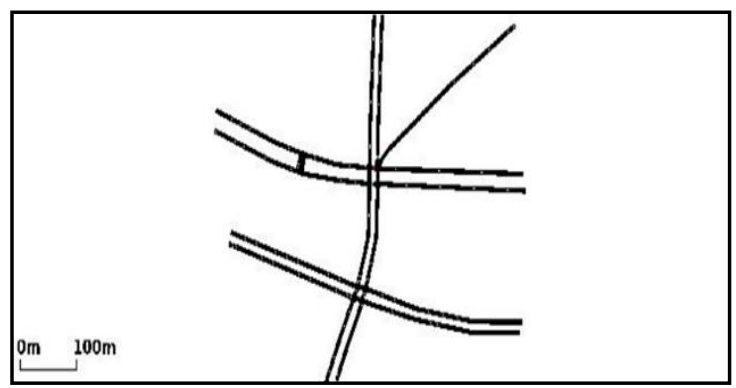

Gambar 5. Peta jalan yang digunakan
Tabel 1. Parameter Simulasi

\begin{tabular}{|l|c|}
\hline Parameter & Nilai \\
\hline Area Simulasi & 1000x1000 (m) \\
\hline $\begin{array}{l}\text { Lingkungan } \\
\text { Simulasi }\end{array}$ & urban \\
\hline Protocol Routing & OLSR, AOMDV \\
\hline Pergerakan Node & Random Way Point \\
\hline Standar Teknologi & IEEE $802.11 \mathrm{p}$ \\
\hline Antena Model & Omnidirectional \\
\hline Jumlah Node & $80,120,160,200$ \\
\hline $\begin{array}{l}\text { Kecepatan } \text { Node } \\
\text { (km/jam) }\end{array}$ & $20,30,40,50$ \\
\hline Traffic Model & CBR, UDP \\
\hline Data Packet Size & $512 \mathrm{~kb}$ \\
\hline Packet Sending Rate & $512 \mathrm{kbps}$ \\
\hline Waktu Simulasi & 200 tik \\
\hline
\end{tabular}

\subsection{Pengaruh Perubahan Jumlah Node}

Skenario perubahan jumlah node ini dilakukan untuk melihat performansi dari kedua routing, yaitu OLSR dan AOMDV dalam menangani perubahan topologi jaringan akibat perubahan jumlah node. Seperti dijelaskan pada data yang ada, bahwa jumlah kendaraan yang melintas di sekitar Jalan Ir.H.Juanda Bandung paling ramai adalah sekitar 4000 kendaraan per jam atau sekitar 200 kendaraan per tiga menit atau sesuai dengan lama simulasi dalam penelitian lakukan. Pada skenario ini sesuai Tabel 2 kecepatan node adalah konstan sesuai batas kecepatan di dalam kota menurut UndangUndang lalu lintas yaitu pada kecepatan 50 $\mathrm{km} / \mathrm{jam}$.

Tabel 2. Skenario Urban dengan perubahan jumlah node

\begin{tabular}{|c|c|c|}
\hline Skenario & $\begin{array}{l}\text { Perubahan } \\
\text { Jumlah Node }\end{array}$ & $\begin{array}{c}\text { Kecepatan Node } \\
(\mathbf{k m} / \mathbf{j a m})\end{array}$ \\
\hline \multirow{4}{*}{ Urban 1} & 80 & \multirow{4}{*}{$\begin{array}{c}50 \mathrm{~km} / \mathrm{jam} \\
\text { Atau setara dengan } \\
13,89 \mathrm{~m} / \mathrm{s}\end{array}$} \\
\hline & 120 & \\
\hline & 160 & \\
\hline & 200 & \\
\hline
\end{tabular}

\subsection{Pengaruh Perubahan Kecepatan pada Lingkungan Perkotaan (urban)}

Skenario ini (sesuai Tabel 3) dilakukan untuk menguji kemampuan kedua protokol routing dalam menghadapi perubahan topologi 
jaringan yang terjadi akibat perubahan kecepatan node yang terjadi di lingkungan perkotaan. Lingkungan perkotaan memiliki karakteristik yaitu pergerakannya lebih lambat daripada highway dan kecepatannya relatif berubah-ubah atau tidak konstan. Jumlah kendaraan yang digunakan adalah 150 node dan kecepatan yang digunakan adalah kecepatan di sekitar batas kecepatan pada lingkungan perkotaan.

Tabel 3. Skenario Urban dengan perubahan kecepatan node

\begin{tabular}{|c|c|c|}
\hline Skenario & $\begin{array}{c}\text { Jumlah } \\
\text { Node }\end{array}$ & $\begin{array}{c}\text { Perubahan Kecepatan } \\
\text { Node }\end{array}$ \\
\hline \multirow{3}{*}{$\begin{array}{c}\text { Skenario } \\
\text { Urban 2 }\end{array}$} & \multirow{3}{*}{150 node } & $20 \mathrm{~km} / \mathrm{jam}$ atau $5,56 \mathrm{~m} / \mathrm{s}$ \\
\cline { 3 - 3 } & & $30 \mathrm{~km} / \mathrm{jam}$ atau $8,33 \mathrm{~m} / \mathrm{s}$ \\
\cline { 3 - 3 } & & $40 \mathrm{~km} / \mathrm{jam}$ atau $11,11 \mathrm{~m} / \mathrm{s}$ \\
\cline { 3 - 3 } & & $50 \mathrm{~km} / \mathrm{jam}$ atau $13,89 \mathrm{~m} / \mathrm{s}$ \\
\hline
\end{tabular}

\section{HASIL DAN PEMBAHASAN}

Hasil dari simulasi routing protocol Optimized Links State Routing (OLSR) dan Adhoc On-Demand Multipath Distance Vector (AOMDV). Simulasi yang dilakukan pada ns-2 menghasilkan file dengan ekstensi tr yang berisi hasil tracing komunikasi antar kendaraan kemudian. Untuk mengolah data dari file tr tersebut digunakan awk script. Setelah didapatkan nilai akhir dari parameter uji kemudian diubah ke dalam bentuk grafik lalu dianalisis.

\subsection{Analisa Performansi Protokol Routing Terhadap Perubahan Jumlah Node}

\subsubsection{Packet Delivery Ratio}

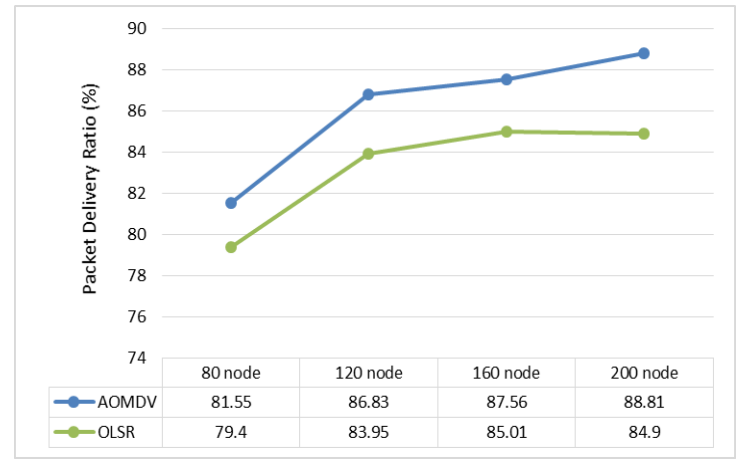

Gambar 6. Pengaruh Perubahan Jumlah Node Terhadap PDR
Packet Delivery Ratio (PDR) dapat menunjukkan tingkat keberhasilan sebuah protokol routing karena semakin tinggi nilai PDR salah satunya disebabkan oleh berhasilnya sebuah protokol routing dalam melakukan pencarian dan pemeliharaan rutenya. Pada Gambar 6 nilai PDR dari kedua protokol routing tidak jauh berbeda, semakin tinggi perubahan jumlah node maka nilai PDR nya akan semakin meningkat. Hal ini menunjukkan bahwa kepadatan jumlah node sangat mempengaruhi keberhasilan transmisi data. Untuk teknologi $802.11 \mathrm{p}$ range transmisi antar node berkisar 250$300 \mathrm{~m}$. Jika node terlalu sedikit akan menyebabkan jarak minimum tersebut tidak dapat terpenuhi sehingga PDR rendah. Walaupun memiliki nilai yang tidak jauh berbeda protokol routing AOMDV lebih unggul sampai mencapai angka $88.81 \%$ pada perubahan jumlah kepadatan node ke 200 dan $81.55 \%$ pada jumlah kepadatan node 80 . Hal itu dapat terjadi karena salah satu kelebihan dari routing protokol AOMDV yaitu update rute dilakukan secara mandiri oleh tiap node dan AOMDV hanya melakukan pencarian rute ketika dibutuhkan saja. AOMDV juga menjamin rute alternatif saling disjoint atau beririsan sehingga rute yang ditemukan kemungkinan tidak akan terjadi loop. Sedangkan pada OLSR yang nilainya tidak terlalu jauh dengan AOMDV pada jumlah kepadatan node 80 yaitu $79.54 \%$ dan node 200 yaitu $84.9 \%$. Karena dengan bertambahnya node maka jarak antara node semakin dekat sehingga kemungkinan terjadinya link failure semakin kecil, dengan semakin jarang terjadinya link failure maka semakin besar pula nilai dari PDR nya.

\subsubsection{Routing Overhead}

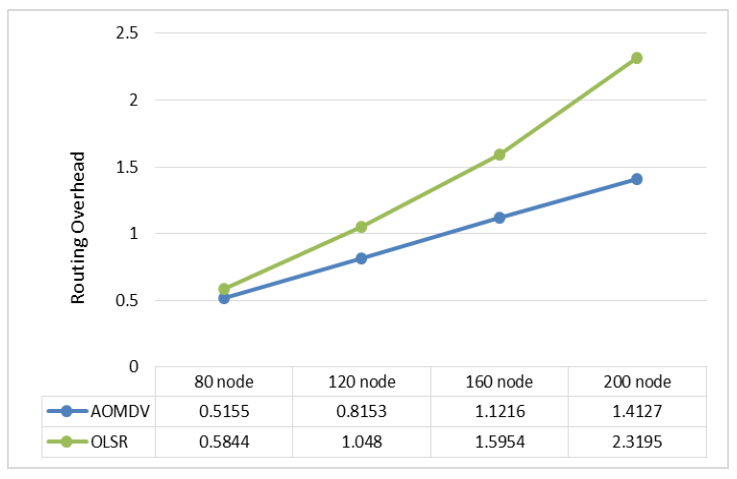

Gambar 7. Pengaruh Perubahan Jumlah Node Terhadap RO 
Routing Overhead ini digunakan untuk menghitung efisiensi kerja suatu routing protocol. Nilai dari RO dipengaruhi oleh peningkatan jumlah node, semakin banyak jumlah node maka semakin besar pula paket yang di butuhkan sehingga semakin besar pula nilai dari RO. Terlihat di Gambar 7 bahwa nilai routing overhead pada OLSR lebih besar jika dibandingkan dengan AOMDV dikarenakan OLSR secara periodik melakukan pengiriman massage control untuk memastikan adanya perubahan topologi atau tidak. Selain itu route discovery nya melibatkan semua node yang menjadi tetangga nya saat mengirimkan pesan RREQ. Sedangkan AOMDV yang memiliki fitur multipath memiliki salah satu keunggulan dibandingkan dengan multipath lainnya yaitu tidak memiliki overhead koordinasi antar node yang tinggi karena komunikasi pada AOMDV hanya dilakukan saat dibutuhkan saja.

\subsubsection{Normalized Routing Load}

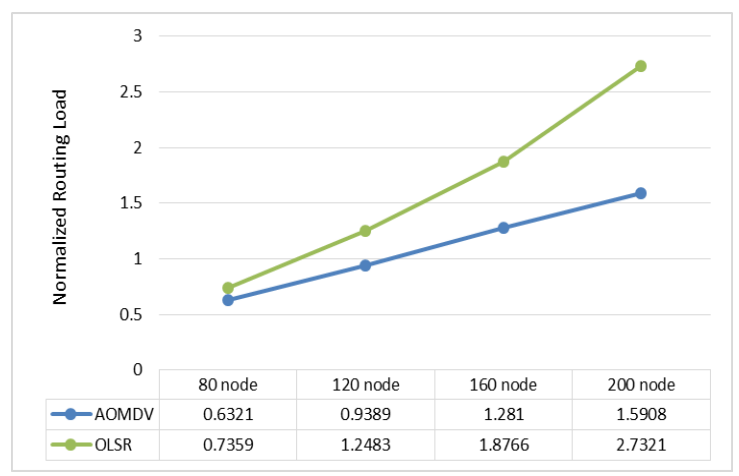

Gambar 8. Pengaruh perubahan jumlah node terhadap NRL

NRL (Normalized Routing Load) merupakan jumlah paket routing yang ditransmisikan per paket data yang diterima di tujuan. Meningkatnya jumlah node menyebabkan nilai routing overhead juga meningkat karena semakin banyak node maka beban protokol dan penggunaan resource akan semakin besar. Oleh karena itu semakin banyak paket routing yang dikirimkan ke jaringan mengakibatkan nilai NRL nya naik. Terlihat di Gambar 8 bahwa hal tersebut menyebabkan performansi protokol routing AOMDV untuk parameter NRL menjadi lebih baik karena nilai nya lebih kecil jika dibandingkan dengan protokol routing OLSR. Hal ini karena routing load yang tinggi menyebabkan pamakaian bandwidth tambahan untuk transmisi sementara bandwidth kanal wireless yang tersedia cukup terbatas maka diharapkan protokol routing dapat mengurangi beban routing tersebut.

\subsubsection{Average End to End Delay}

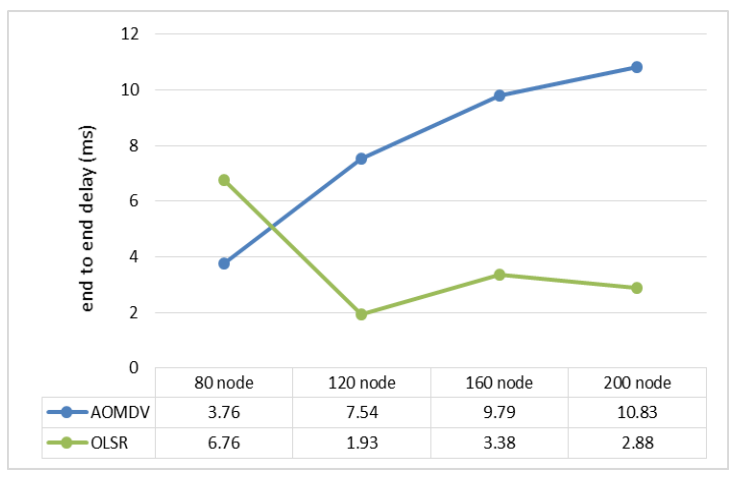

Gambar 9. Pengaruh Perubahan Jumlah Node Terhadap Delay

End to end delay adalah waktu yang dibutuhkan dalam pengiriman data dari source node ke destination node. Dalam proses pengiriman data, tentunya data akan dipengaruhi oleh banyak faktor yang mengakibatkan delay. Terlihat di Gambar 9 bahwa hasil grafik perubahan jumlah node kedua protokol routing tidak membentuk pola yang teratur. Grafik protokol routing OLSR naik turun tidak beraturan. Pola grafik yang tidak teratur seperti ini dapat terjadi karena dalam durasi waktu simulasi untuk jumlah node yang disimulasikan misalnya 200, tidak tetap 200 node dalam 200 detik simulasi. Node yang masuk terlebih dahulu akan hilang terlebih dahulu pula. Hal ini bisa jadi mempengaruhi waktu yang dibutuhkan paket data untuk sampai di tujuan. Pada sekenario perubahan jumlah kepadatan node ini OLSR mengungguli AOMDV dari rata-rata nilai yang di dapat. Bisa dikarenakan setiap node pada routing ini memiliki perhitungan sendiri untuk mencapai suatu node dengan menggunakan algoritma shortest-path, sehingga delay-nya sedikit lebih kecil dari AOMDV. Tetapi secara umum nilai end to end delay dari kedua algoritma tersebut masih diperbolehkan untuk jenis komunikasi safety messages pada jaringan VANET dimana nilai end to end delay maksimum yang diperbolehkan adalah $100 \mathrm{~ms}$. 


\subsubsection{Average Throughput}

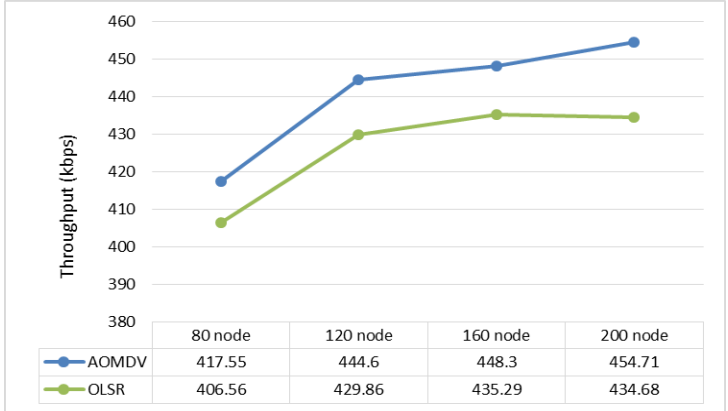

Gambar 10. Pengaruh Perubahan Jumlah Node Terhadap Throughput

Throughput menggambarkan kondisi data rate dalam suatu jaringan. Ada beberapa hal yang mempengaruhi nilai throughput, salah satunya adalah ketahanan dari link yang terbentuk dan proses pencarian jalur hingga jalur tersebut terbentuk. Pada Gambar 10 nilai throughput kedua algoritma routing protocol tidak jauh berbeda, terlihat dari grafiknya yang sama-sama menanjak naik menunjukkan semakin banyak jumlah node maka nilai throughput akan semakin meningkat. Jika semakin banyak node dalam sebuah jaringan akan semakin kecil kemungkinan terjadinya link failure. Sehingga daya tahan link lebih lama karena jika terjadi link failure mengakibatkan algoritma routing berada dalam kondisi route discovery. Maka pemilihan rute terbaik akan menentukan performansi suatu routing protocol. Nilai throuhput juga ikut mempengaruhi rasio PDR. Nilai throughput AOMDV secara keseluruhan pada skenario perubahan jumlah node ini lebih baik daripada OLSR.

\subsection{Analisa Performansi Protokol Routing Terhadap Perubahan Kecepatan Node Packet Delivery Ratio}

\subsubsection{Packet Delivery Ratio}

Packet Delivery Ratio (PDR) adalah jumlah paket yang berhasil diterima oleh node tujuan berbanding dengan total paket yang dikirim oleh node sumber. Dalam mengukur performansi sebuah routing protocol dalam pengiriman paket data PDR dipengaruhi oleh nilai throughput. Kinerja dari PDR akan memberikan gambaran tentang seberapa baik suatu protokol dalam hal pengiriman paket data pada kecepatan yang bervariasi.

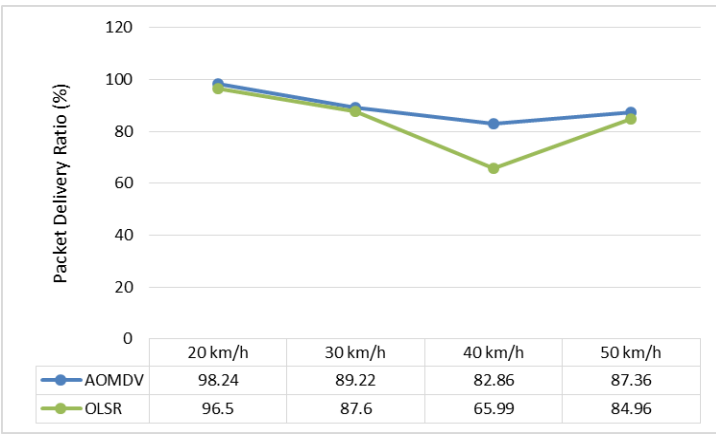

Gambar 11. Pengaruh Perubahan Kecepatan Node Terhadap PDR

Terlihat di Gambar 11 bahwa grafik menunjukkan kedua protokol cenderung menurun ketika kecepatan node semakin tinggi, tetapi di kecepatan node $50 \mathrm{~km} / \mathrm{jam}$ nilai dari PDR kembali naik. Hal ini dikarenakan banyaknya persimpangan di dalam skenario urban serta perpaduan kecepatan dan jumlah node didalam skenario, jika kecepatan semakin dinaikkan maka jarak antar node juga semakin jauh menyebabkan terjadi putusnya jalur yang berakibat pada pengulangan pencarian route baru. Pada skenario perubahan kecepatan node ini protokol routing AOMDV lebih efisien daripada OLSR dapat disebabkan karena AOMDV memiliki fitur multipath sehingga dapat memilih jalur alternatif yang banyak, jika salah satu dari jalur utama terputus maka akan langsung di ganti oleh jalur alternatif lainnya.

\subsubsection{Routing Overhead}

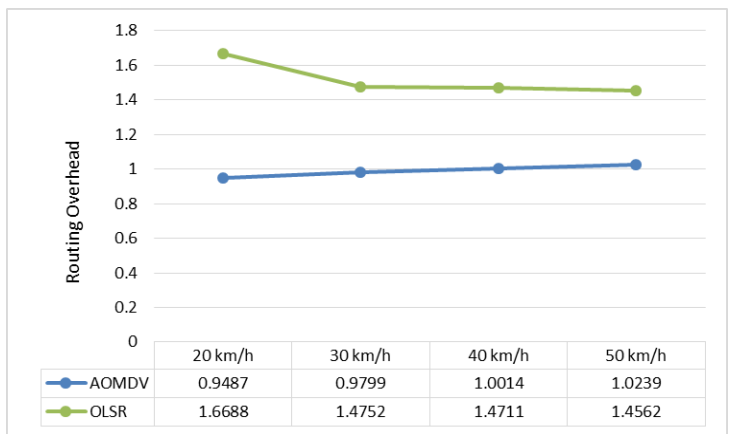

Gambar 12. Pengaruh Perubahan Kecepatan Node Terhadap RO

Routing Overhead adalah perbandingan antara banyaknya paket routing yang ditransmisikan oleh protokol routing selama simulasi dibagi banyaknya paket yang dikirim 
oleh node source ke node destination, parameter ini menunjukan efisiensi kerja suatu routing protocol. Pada Gambar 12 terlihat di grafik bahwa AOMDV lebih unggul dibandingkan OLSR karena memiliki nilai yang lebih kecil. Hal ini karenakan routing protokol OLSR secara periodik melakukan pengiriman message control untuk memastikan apakah ada perubahan topologi atau tidak, dan sifat recovery melibatkan semua node yang ada dalam jangkauan topologi. Sedangkan AOMDV yang merupakan routing protokol multipath menemukan alternatif rute dengan tambahan overhead yang minim. Hal tersebut dilakukan dengan memanfaatkan semaksimal mungkin informasi routing jalur alternative yang sudah ada.

\subsubsection{Normalized Routing Load}

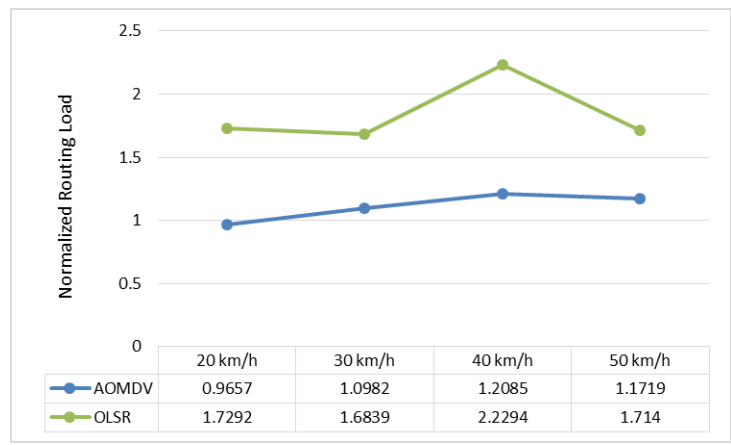

Gambar 13. Pengaruh Perubahan Kecepatan Node Terhadap NRL

Karena bandwidth kanal wireless terbatas
maka diharapkan protokol routing meminimalisasi jumlah dan ukuran paket control. Dari Gambar 13 dapat dilihat NRL dari protokol routing AOMDV terus meningkat seiring bertambahnya kecepatan dan menurun kembali pada kecepatan $40 \mathrm{~km} / \mathrm{jam}$. Hal ini dapat terjadi disebabkan adanya link failure atau kegagalan rute akibat perubahan topologi jaringan yang semakin besar. Ketika terjadi link failure protokol routing akan mencari jalur alternatif lain atau dilakukan pencarian rute kembali jika seluruh jalur alternatif yang ada juga mengalami kegagalan. Sedangkan pada OLSR grafik nya turun pada kecepatan 30 $\mathrm{km} / \mathrm{jam}$ lalu kembali naik pada kecepatan $40 \mathrm{~km} /$ jam dan turun kembali di kecepatan $50 \mathrm{~km} / \mathrm{jam}$ dapat disebabkan karena OLSR merupakan protokol routing yang proaktif yang menentukan tabel routing-nya dengan meng-update setiap waktu jika terjadi perubahan link. Pada tiap perubahan kecepatan node AOMDV mengungguli nya.

\subsubsection{Average End to End Delay}

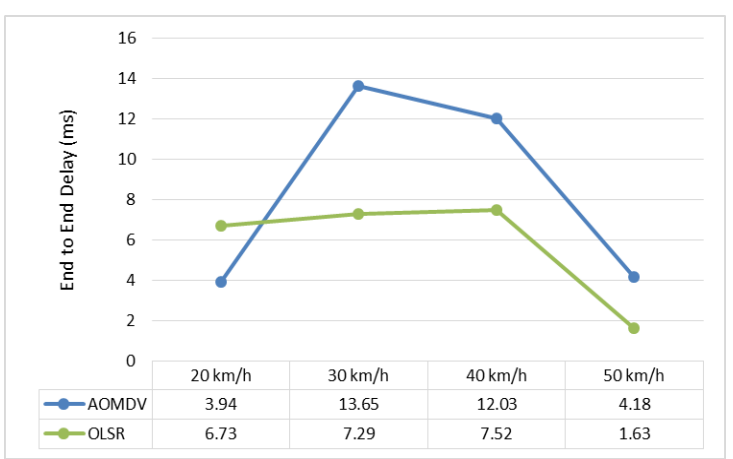

Gambar 14. Pengaruh Perubahan Kecepatan Node Terhadap Delay

End to end delay adalah jumlah waktu yang digunakan oleh sebuah paket ketika dikirim oleh sebuah node dan diterima di node tujuan. Faktor yang sangat mempengaruhi end to end delay adalah waktu untuk routing protocol tersebut dalam menemukan route, hal ini dikarenakan sebelum mengirim pesan, source node terlebih dahulu harus mengetahui route yang menghubungkan ke destination. Faktor lain yang mempengaruhi end to end delay adalah delay proses. Ketika node yang ditengah menerima sebuah pesan, node tersebut akan menganalisa header untuk mengetahui untuk siapa paket tersebut ditujukan, dan kemudian mengecek kemana harus meneruskan paket tersebut. Berdasarkan Gambar 14 Nilai end to end delay terus meningkat seiring dengan bertambahnya kecepatan tetapi kembali turun pada kecepatan $50 \mathrm{~km} / \mathrm{jam}$. Grafik terus menanjak dapat disebabkan karena semakin cepat pergerakan node maka penumpukan kendaraan akan terjadi. OLSR memiliki nilai end-to-end delay rata-rata yang lebih baik dibandingkan dengan AOMDV dapat dikarenakan setiap node pada OLSR mengirimkan pesan kontrol secara berkala dan tidak melakukan pengiriman pesan berurutan. Lalu tingginya kecepatan node berpengaruh pada nilai delay. Semakin tinggi kecepatan, semakin tinggi juga kemungkinan terjadi perubahan topologi dan kegagalan route atau link failure. Tetapi delay pada protokol routing 
AOMDV masih diperbolehkan untuk jenis komunikasi safety messages pada jaringan VANET dimana nilai end to end delay maksimum yang diperbolehkan adalah $100 \mathrm{~ms}$.

\subsubsection{Average Throughput}

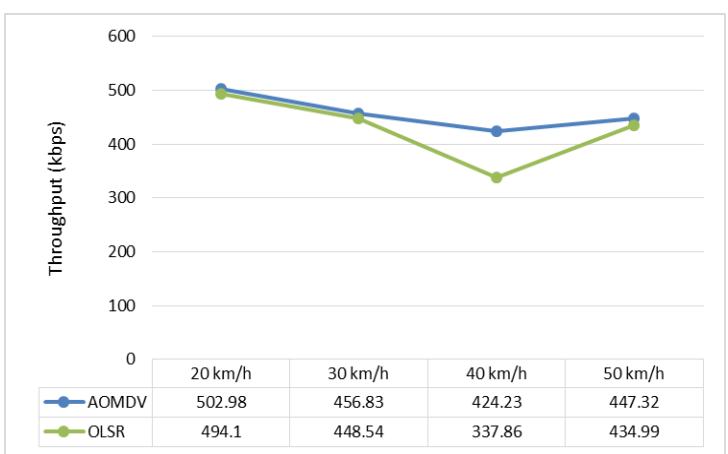

Gambar 15. Pengaruh Perubahan Kecepatan Node Terhadap Throughput

Banyak hal yang dapat mempengaruhi nilai throughput salah satunya adalah bentuk daya tahan dari link yang terbentuk, semakin sering topologi berubah semakin sering kemungkinan terjadinya link failure dan mengakibatkan algoritma routing berada dalam kondisi route discovery, sehingga pemilihan rute terbaik akan menentukan performansi suatu routing protocol. Nilai throuhput juga ikut mempengaruhi rasio PDR, semakin tinggi nilai throughput maka protokol routing memiliki performa yang lebih baik. Nilai throughput AOMDV secara keseluruhan lebih besar daripada OLSR untuk semua skenario perubahan kecepatan node. Nilai throughput menurun seiring menigkatnya kecepatan suatu node dapat disebabkan pola pergerakan node di lingkungan urban yang tidak konstan. Contohnya pada keadaan macet akan terjadi penumpukan sekumpulan node yang menyebabkan node tersebut diam untuk sesaat. Sehingga proses pengiriman datanya lebih cepat, dapat dilihat dari nilai throughput yang tinggi pada kecepatan $20 \mathrm{~km} / \mathrm{jam}$.

\section{KESIMPULAN}

Setelah dilakukan simulasi dan analisa terhadap kedua algoritma routing protocol yaitu OLSR dan AOMDV, maka dapat diambil kesimpulan bahwa AOMDV lebih unggul hampir pada semua metrik performansi dengan nilai rata-rata Packet Delivery Ratio $87.804 \%$; Throughput 449.565 kbps; Routing Overhead 0.9773; dan Normalized routing load 1.1108. Sedangkan pada OLSR memiliki rata-rata Packet Delivery Ratio 83.539\%; Throughput 427.735 kbps; Routing Overhead 1.4523; Normalized routing load $1.7436 . \quad$ Karena AOMDV lebih unggul empat dari lima metrik performansi yang diujikan ini dapat menunjukkan bahwa protokol routing AOMDV lebih efisien diterapkan pada jaringan vehicular ad-hoc network (VANET) pada kondisi perkotaan. Tetapi pada metrik performansi end to end delay OLSR lebih unggul dengan memiliki nilai rata-rata 4.765 ms. Sedangkan pada AOMDV memiliki nilai 8.215 ms. Namun keduanya masih diperbolehkan untuk jenis komunikasi safety messages pada jaringan VANET dimana nilai end to end delay maksimum yang diperbolehkan adalah $100 \mathrm{~ms}$. Kemudian nilai rata-rata Packet Delivery ratio dari AOMDV dan OLSR masing-masing adalah $87.803 \%$ dan $83.539 \%$. Hal ini menunjukan bahwa keberhasilan pengiriman data dari kedua protokol routing tidak jauh berbeda hanya AOMDV sedikit lebih unggul. Dilihat dari nilai rata-rata routing overhead dan normalized routing load dari AOMDV adalah 0.9773; 1.1108; dan pada OLSR adalah $1.4523 ; 1.7436$. AOMDV lebih unggul karena kelebihan dari AOMDV yang bersifat on demand sehingga routing packet yang dihasilkan lebih kecil.

Dari hasil yang di dapat perubahan jumlah node dan perubahan kecepatan node mempengaruhi performansi dari routing protocol. Semakin banyak jumlah node yang ada maka akan meningkatkan keberhasilan suatu transmisi data. Begitu juga pada perubahan kecepatan semakin cepat suatu node akan menyebabkan jarak antar node semakin jauh dan menyebabkan kemungkinan terjadinya link failure akan semakin tinggi.

\section{DAFTAR PUSTAKA}

[1] Harri, Jerome, dkk.. 2009. Vehicular Mobility Simulation with VanetMobiSim. Trans. of Society for Modelling and Simulation

[2] Amirhossein Moravejosharieh1, Hero Modares, Rosli Salleh and Ehsan Mostajeran. Performance Analysis of AODV, AOMDV, DSR, DSDV Routing 
Protocols in Vehicular Ad Hoc Network. Research Journal of Recent Sciences Vol. 2(7), 66-73 July (2013)

[3] U. Nagaraj, M.U. Kharat, and P. Dhamal, "Study of Various Routing Protocols in VANET," International Journal of Computer Science and Technology (IJCST), Vol.2, Issue 4, 2011

[4] Puneet Mittal, Paramjeet Singh, Shaveta Rani "Performance Analysis Of AODV, OLSR, GRP and DSR Routing Protocols with Database Load In MANET" Dept. of Computer Engineering Govt, Poly. College, Bathinda, Punjab, India.

[5] Jain Trapati, Shiwani Savita .2010. "Analisis of OLSR, DYMO, DSR Routing Protocol in Mobile Adhoc Network using omnet simulation.

[6] Saad Talib Hasson adn Sura Jasim. "Simulation Study to Observe the Effects of Increasing Each of The Network Size and the Network Area Size on MANET's Routing Protocol'Dean of Al-Musyab College for Engineering and TechnologyUniversity of Babylon, Iraq.(Received: March 05, 2014; Accepted: March 15, 2014)

[7] Acropolis Institute of Technology \& Research, Computer Science \& Engineering, Indore, India. Analysis of Performance Matrices of OLSR, AOMDV \& ZRP Protocols in the VANET Scenario. [Dubey, 3(2): February, 2014]

[8] Mahesh K. Marina, Samir R. Das. 2006. Ad hoc on-demand multipath distance vector routing. USA

\section{Biodata Penulis}

Rianda Anisia, ST. lahir di Mataram tanggal 22 Agustus 1993, mahasiswa Teknik Telekomunikasi Fakultas Teknik Elektro Universitas Telkom.

Dr. Ir. Rendy Munadi., MT. Dosen S1 Teknik Telekomunikasi Fakultas Teknik Elektro Universitas Telkom. Sebagai dosen di Universitas Telkom, saat ini aktif sebagai Ketua Keahlian Jaringan Multimedia serta melakukan riset dan publikasi mengenai wireless sensor network, software define network serta compressive sensing.
Ridha Muldina Negara, ST., MT. Dosen S1 Teknik Telekomunikasi Fakultas Teknik Elektro Universitas Telkom. Sebagai dosen di Universitas Telkom saat ini aktif di Kelompok Keahlian Jaringan Multimedia, saat ini aktif melakukan riset dan publikasi mengenai VANET, software define network serta standar IEEE 802.11 ah. 